\title{
THE IMPACT OF THE LENGTH OF POLYPROPYLENE FIBERS ON SELECTED PROPERTIES OF CONCRETE
}

\author{
Alina Pietrzak ${ }^{\bowtie}$, Małgorzata Ulewicz \\ Faculty of Civil Engineering, Częstochowa University of Technology, Częstochowa
}

\begin{abstract}
Concrete, being one of the most important construction materials, despite many advantages (ease of handling, high compressive strength, low production cost, heat resistance) it also has many disadvantages, including low tensile strength as well as sensitivity to destructive action of chemical agents. A constant growth in expectations concerning increasing the quality of concrete led to its polymer modification, whose aim was to eliminate above-mentioned disadvantages. The scope of the present research involved designing and making of concrete mixtures modified by 6,12 and $19 \mathrm{~mm}$ long polypropylene fibres. For the experiment the authors used: Portland cement CEM I 42.5R, sand, gravel aggregate of the 2-8 and 8-16 fractions, water, Master Pozzolith STD plasticizer and polypropylene fibres of various length. The authors made three series of concrete samples modified by fibres, for which the following factors have been assigned: compression strength after 7,28 and 56 days of maturing as well as absorptivity, volumetric density and frost resistance after 100 cycles of freezing and thawing. There was also conducted the flexural tensile-strength test after 28 days of maturing of concrete samples of the particular series.
\end{abstract}

Key words: polypropylene fibers, concrete, compressive strength

\section{INTRODUCTION}

Concrete and steel are the most commonly used construction materials, which form the image of the contemporary architecture. A constant growth of the quality of these products is caused by both an increase in users' expectations and an increase in demands determined by certain regulations (Kakooei, Hazizan, Jamshidi \& Rouhi, 2012; Nowicka-Skowron \& Ulewicz, 2015; Ansari \& Sharma, 2017). Polymers, as modifiers, have been used to improve the concrete quality for over fifty years (Chandra, 1995; Ulewicz, Selejdak, Borkowski \& Jagusiak-Kocik, 2013). The group of polymer concretes include: resin concrete (PC), polymer-cement concrete (PCC), polymer impregnated concrete (PIC) (Czarnecki, 2010; Sharma \& Bansal, 2016). Moreover the plastic fibers are used in concrete is to enhance the mechanical and durability properties of conventional concrete. For this purpose, both commercial fibers and obtained from waste materials are used (Wang, Wu \& Li, 2000; Han, Hwang, Yang \& Gowripalan, 2005; Ochi, Okubo \& Fukui, 2007; Kim, Yi, Kim, Kim \& Song, 2010; Karahan \& Atis, 2011; Nibudey, Nagarnaik, Parbat \& Pande, 2013; Gu \& Ozbakkaloglu, 2016; Krupińska \& Mariak, 2016). The use plastic fibers as reinforcement to replace steel fibers in concrete has ecologic and ecological benefits, because steel is expensive and susceptible to corrosion. Whereas, plastic fibers are cost-effective, have lower carbon footprint and are corrosion resistant. 
The plastics are used in concrete mainly in two forms: as plastic aggregates (PA), which replace natural aggregates and plastic fibers (PF), which are used in fiber-reinforced concrete (FRC) (Chen \& Liu, 2004; Choi, Moon, Chung \& Cho, 2005; Tang, Lo \& Nadeem, 2008; Choi, Moon, Kim \& Lachemi, 2009; Kan \& Demirboða, 2009; Fraternali et al., 2011).

According to requirements of the standard PN-EN 14889-2:2007, polypropylene fibres are defined as straight or deformed fragments of extruded, oriented and cut polymer material, useful in homogeneous mixing with concrete or mortar. Polymers listed in the standard comprise, for example polypropylene, polyethylene, polyester, nylon, polyvinyl alcohol, polyacryl, aramid and their mixtures.

The standard classification of polymer fibres refers to their physical form.

- Class Ia - microfibers: diameter $<0.30 \mathrm{~mm}$; single;

- Class Ib - microfibers: diameter $<0.30 \mathrm{~mm}$; fibrillated;

- Class II - macrofibres: diameter $>0.30 \mathrm{~mm}$.

A literature review shown that in laboratory both a commercial plastics fibers (according to the standard norm) and plastics wastes are used. Concrete modified by polypropylene fibres is used for making industrial flooring, road and airport surfaces, and prefabricated thin-walled elements. The main advantage of using such fibres is to prevent the occurrence of anti-shrinkage cracks in "young" maturing concrete. However, having reached the resistance designed and the modulus of elasticity such fibres cease to work. Then, the stresses are transferred by concrete itself or main anchoring bars.

Most often, in the publications the results of research on the properties of mechanical materials with the addition of polymers fibres are presented. However, there are no detailed reports on the properties of polymeric materials used and their influence on the properties of made concrete composites (Krupińska \& Mariak, 2016). Therefore the aim of the paper was to determine the influence of the length of the polypropylene fibre on the basic properties of concrete.

\section{EXPERIMENTAL}

For the experiment the authors used: Portland cement CEM I 42.5R, sand, gravel aggregate of the 2-8 and 8-16 mm fractions, water, Master Pozzolith STD plasticizer and polypropylene fibres of various length (Table 1).

Table 1. Properties of polypropylene fibres used in the study

\begin{tabular}{lcccc}
\hline $\begin{array}{l}\text { Fibre } \\
\text { designation }\end{array}$ & shape & colour & $\begin{array}{c}\text { diameter } \\
{[\mu \mathrm{mm}]}\end{array}$ & $\begin{array}{c}\text { fibre length } \\
{[\mathrm{mm}]}\end{array}$ \\
\cline { 4 - 5 } F1 & round & white & $34 \pm 5 \%$ & $\frac{6 \pm 1.5}{12 \pm 1.5}$ \\
\hline F2 & & & $19 \pm 1.5$ \\
\hline F3 & & & & \\
\hline
\end{tabular}

Samples for the research were made in forms according to requirements of the standard PN-EN 12390$-1: 2013-03$. For all series of concrete samples there were twelve $15 \times 15 \times 15 \mathrm{~cm}$ cubic samples, twelve $10 \times 10 \times 10 \mathrm{~cm}$ samples and three $15 \times 15 \times 60 \mathrm{~cm}$ beams, formed according to standard PN-EN 12390$-2: 2011$. The experiment of durability of compressive strength was conducted after 7, 28 and 56 days of sample maturing under laboratory conditions according to standard PN-EN 206:2014. The experiment was carried out by means of the Toni Technik type 2030 testing machine according to the standard (Fig. 1).

Using direct method (PN-88/B-06250) the authors conducted a study of concrete frost-resistance for a F100 resistance class. After 28 days of maturation,
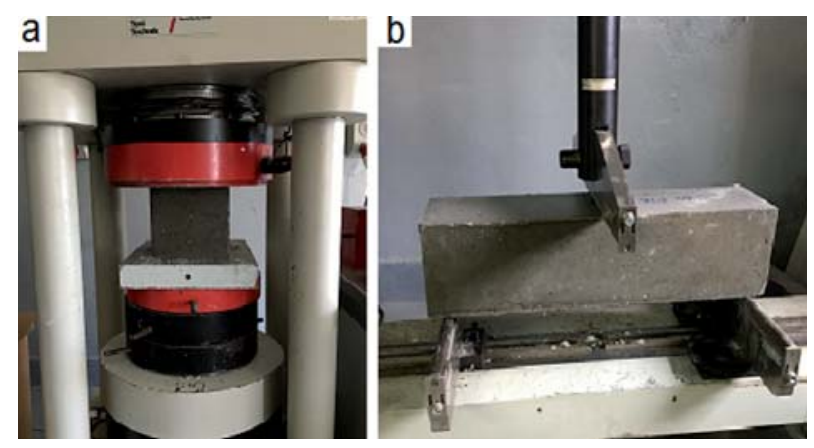

Fig. 1. Strength test on: $\mathrm{a}$ - compression; $\mathrm{b}$ - flexural tensile-strength 
the frost resistance test was started according to the standard. The samples were placed in a freezer compartment where the air temperature was $-18^{\circ} \mathrm{C} \pm 2^{\circ} \mathrm{C}$. The freezing time was $4 \mathrm{~h}$. After this time, samples were thawed in water at $+18^{\circ} \mathrm{C} \pm 2^{\circ} \mathrm{C}$ for $4 \mathrm{~h}$. This is one cycle. After the last cycle, the samples were weighed and compressed.

In this work, four series of samples were made. Control concrete sample with the $\mathrm{w} / \mathrm{c}$ ratio with equal 0.55 the addition of plasticizer in the amount of $0.3 \%$ of the cement bulk - $(1 \mathrm{~K})$ series. In the subsequent attempts the control concrete was modified with polypropylene fibres (F1-F3 series) in the amount of $0.9 \mathrm{~kg} \cdot \mathrm{m}^{-3}$.

\section{RESULTS AND DISCUSSION}

The research results on the compression strength, absorptivity and concrete density for particular series are presented in Table 2. The average compressive strength of the control concrete series $(1 \mathrm{~K})$ measures after 7 days equalled $f_{c m}=38.2 \mathrm{MPa}$. Adding polypropylene fibres caused a slight increase in average compressive strength for two of the modified series. After 7 days of maturing, the biggest, $3.4 \%$ increase of compressive strength in relation to the control concrete series was observed in F2 and F3 series. The 9.5\% decrease, in compressive strength was examined in F1 series. The average compressive strength of the control concrete series $(1 \mathrm{~K})$, measures after 28 days $f_{c m}=46.7 \mathrm{MPa}$. The average compressive strength, gained in $\mathrm{F} 1$ series, was on the similar level as in the control series and it equalled 46.7 MPa. An increase of the compressive strength in relation to the $1 \mathrm{~K}$ series was noticed in F2 and $\mathrm{F} 3$ concrete series (1.7 and 4.4\%, respectively).

The average compressive strength of the control concrete series $(1 \mathrm{~K})$, measured after 56 days of maturing $f_{c m}=51.4 \mathrm{MPa}$. In all concrete series (F1 and F3) modified by fibres the average compressive strength was on the similar level as in the control series.

On the basis of the methodology included in standard PN-88/B-06250, an experiment of absorbability of particular series was conducted and the findings are presented in Table 2. According to the above-mentioned standard, the absorbability of concrete exposed to environmental influences should not be bigger than $5 \%$. However, for concrete protected from direct weather conditions should not be bigger than $9 \%$. Both the control concrete series and the polypropylene fibre modified concrete reached the absorbability within $5.4-5.6 \%$.

The flexural tensile-strength test of concrete samples of particular series was conducted in accorance with the standard PN-EN 206-1:2014 and the results are presented in Figure 1. The average flexural tensile-strength of the control concrete sample $(1 \mathrm{~K})$, measured after 28 days equalled $2.5 \mathrm{MPa}$. For the series including polimere fibres, F1-F3, there were obtained results of 2.4, 2.4 and $2.5 \mathrm{MPa}$, respectively.

Using direct method (PN-88/B-06250) the authors conducted a study of concrete frost-resistance for a F100 resistance class. The results are presented on Figure 2. The analytical determination is taken as positive if after carrying out of $n$ cycles of freezing and

Table 2. Results of compression strength, absorptivity and concrete density for particular series

\begin{tabular}{|c|c|c|c|c|c|c|}
\hline \multirow{2}{*}{$\begin{array}{l}\text { Concrete } \\
\text { series }\end{array}$} & \multicolumn{3}{|c|}{$\begin{array}{c}\text { Average compression strength }\left(f_{c m}\right) \\
{[\mathrm{MPa}]}\end{array}$} & \multirow{2}{*}{$\begin{array}{c}\text { Absorptivity }\left(n_{w}\right) \\
{[\% \text { mass }]}\end{array}$} & \multirow{2}{*}{$\begin{array}{c}\text { Volumetric } \\
\text { density }(\rho) \\
{\left[\mathrm{kg} \cdot \mathrm{m}^{-3}\right]}\end{array}$} & \multirow{2}{*}{$\begin{array}{c}\text { Average flexural } \\
\text { tensile strength } \\
{[\mathrm{MPa}]}\end{array}$} \\
\hline & $\begin{array}{l}\text { after } 7 \text { days of } \\
\text { maturing }\end{array}$ & $\begin{array}{l}\text { after } 28 \text { days of } \\
\text { maturing }\end{array}$ & $\begin{array}{l}\text { after } 56 \text { days of } \\
\text { maturing }\end{array}$ & & & \\
\hline $1 \mathrm{~K}$ & 38.2 & 46.7 & 51.4 & 5.5 & 2283 & 2.5 \\
\hline $\mathrm{F} 1$ & 34.6 & 46.6 & 48.3 & 5.5 & 2259 & 2.4 \\
\hline $\mathrm{F} 2$ & 39.4 & 47.5 & 51.5 & 5.4 & 2260 & 2.4 \\
\hline F3 & 39.5 & 48.8 & 51.7 & 5.6 & 2293 & 2.5 \\
\hline
\end{tabular}




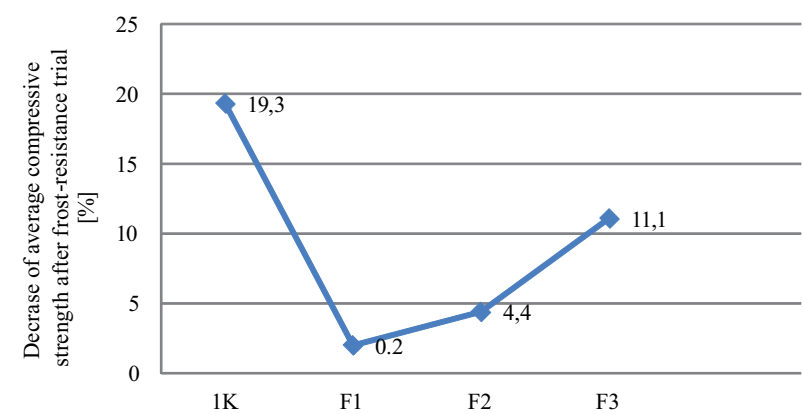

Fig. 2. Decrease of average compressive strength of particular concrete series after frost-resistance trial

thawing, required by certain frost resistance class: the average decrease of compressive strength does not exceed $20 \%$, the average loss in mass does not exceed $5 \%$ and none of the examined samples breaks or scratches. The decrease of resistance for alternate freezing and thawing of the control series equalled $19.3 \%$. As presented in Figure 2 the F1-F3 concrete series modified by polypropylene fibres showed much smaller decrease of resistance for alternate freezing and thawing in relation to the control series. The smallest decrease of strength after concrete frost-resistance trial was noticed in F1 series and it equalled 2.0\%. For F2 and F3 series the decrease of strength equalled 4.4 and $11.1 \%$, respectively. The loss of mass for all concrete series was in the range of between $0.11-0.39 \%$.

\section{CONCLUSIONS}

Concrete series modified by 6,12 and $19 \mathrm{~mm}$ long polypropylene fibres obtained comparable drainage durability in relation to the control series. Along with the growth of the fibre length in the range of between 6-19 mm, a slight increase in compressive strength of concrete. Series of concrete modified by polypropylene fibres demonstrated better resistance to freezing and thawing, as they obtained a smaller decrease in compressive strength in relation to the control series. The smallest decrease of compressive strength, equalling $2.0 \%$, after frost-resistance trials demonstrated concrete samples containing fibres of $6 \mathrm{~mm}$ length. The length of polymer fibers did not affect the tensile strength when bending. For all the tested series it was at the level of $2.5 \mathrm{MPa}$. Also, the length of the polymer fibers used does not affect the absorbability of concrete.

\section{REFERENCES}

Ansari, S. \& Sharma, H. S. (2017). Comparison of properties of Fiber Mix Reinforced Concrete and Conventional Concrete. International Journal of Engineering Science, 7, 12202-12205.

Chandra, S. (1995). Historical background of polymers used in concrete. In Proceedings of $8^{\text {th }}$ International Congress on Polymers in Concrete, Oostende (pp. 3-11). Leuven: KU Leuven.

Chen, B. \& Liu, J. (2004). Properties of lightweight expanded polystyrene concrete reinforced with steel fiber. $\mathrm{Ce}$ ment and Concrete Research, 34, 1259-1263.

Choi, Y. W., Moon, D. J., Kim, Y. J. \& Lachemi, M. (2009). Characteristics of mortar and concrete containing fine aggregate manufactured from recycled waste polyethylene terephthalate bottles. Construction and Building Materials, 23, 2829-2835.

Choi, Y. W., Moon, D-J., Chung, J-S. \& Cho, S-K. (2005). Effects of waste PET bottles aggregate on the properties of concrete. Cement and Concrete Research, 35, 776-781.

Czarnecki, L. (2010). Polymer concretes. Cement Wapno Beton, 77(2), 63-85.

Fraternali, F., Ciancia, V., Chechile, R., Rizzano, G., Feo, L. \& Incarnato, L. (2011). Experimental study of the thermo-mechanical properties of recycled PET fiber-reinforced concrete. Composite Structures, 93, 2368-2374.

Gu, L. \& Ozbakkaloglu, T. (2016). Use of recycled plastics in concrete: A critical review. Waste Management, 51, 19-42.

Han, C-G., Hwang, Y-S., Yang, S-H. \& Gowripalan, N. (2005). Performance of spalling resistance of high performance concrete with polypropylene fiber contents and lateral confinement. Cement and Concrete Research, 35, 1747-1753.

Kim, S. B., Yi, N. H., Kim, H. Y., Kim, J-H. J. \& Song, Y-C. (2010). Material and structural performance evaluation of recycled PET fiber reinforced concrete. Cement \& Concrete Composites, 32, 232-240.

Kakooei, S., Hazizan, M. A., Jamshidi, M. \& Rouhi, J. (2012). The effects of polypropylene fibers on the properties of reinforced concrete structures. Construction and Building Materials, 27, 73-77.

Kan, A. \& Demirboða, R. (2009). A new technique of processing for waste-expanded polystyrene foams as aggre- 
gates. Journal of Materials Processing Technology, 209, 2994-3000.

Karahan, O. \& Atis, C. D. (2011). The durability properties of polypropylene fiber reinforced fly ash concrete. $\mathrm{Ma}$ terials and Design, 32, 1044-1049.

Kurpińska, M. \& Mariak, A. (2016). Polymer fiber reinforced concrete as an alternative to steel fiber. Materiaty Budowlane, 2, 42-44.

Nibudey, R., Nagarnaik, P., Parbat, D. \& Pande, A. (2013). Strength and fracture properties of post consumed waste plastic fiber reinforced concrete. International Journal of Advances in Engineering \& Technology, 3, 9-16.

Nowicka-Skowron, M. \& Ulewicz, R. (2015). Quality management in logistics processes in metal branch. In $24^{\text {th }}$ International Conference on Metallurgy and Materials (pp. 1707-1712). Brno: TANGER.

Ochi, T., Okubo, S. \& Fukui, K. (2007). Development of recycled PET fiber and its application as concrete-reinforcing fiber. Cement \& Concrete Composites, 29, 448-455.

Ulewicz, R., Selejdak, J., Borkowski, S. \& Jagusiak-Kocik, M. (2013). Process management in the cast iron foundry. In Metal 2013: 22nd International Conference on Metallurgy and Materials, Brno (pp. 1926-1931). Ostrava: TANGER.

Sharma, R. \& Bansal, P. (2016). Use of different forms of waste plastic in concrete e a review. Journal of Cleaner Production, 112, 473-482.

Tang, W., Lo, Y. \& Nadeem, A. (2008). Mechanical and drying shrinkage properties of structural-graded polystyrene aggregate concrete. Cement \& Concrete Composites, 30 , 403-409.

Wang, Y., Wu, H. \& Li, V. C. (2000). Concrete reinforcement with recycled fibers. Journal of Materials in Civil Engineering, 12, 314-319.

PN-88/B-06250. Beton zwykły [Concrete].

PN-EN 206:2014-04. Beton. Wymagania właściwości, produkcja i zgodność [Concrete. Specification, performance, production and conformity].

PN-EN 12390-1:2013-03. Badania betonu. Część 1: Kształt, wymiary i inne wymagania dotyczące próbek do badań i form [Testing hardened concrete. Part 1: Shape, dimensions and other requirements for specimens and moulds].

PN-EN 12390-2:2011. Badania betonu. Część 2: Wykonywanie i pielęgnacja próbek do badań wytrzymałościowych [Testing hardened concrete. Part 2: Making and curing specimens for strength tests].

PN-EN 14889-2:2007. Włókna do betonu. Część 2: Włókna polimerowe. Definicje, wymagania i zgodność [Fibres for concrete. Part 2: Polymer fibres. Definitions, specifications and conformity].

\section{WPŁYW DŁUGOŚCI WŁÓKIEN POLIPROPYLENOWYCH NA WYBRANE WŁAŚCIWOŚCI BETONU}

\section{STRESZCZENIE}

Beton, stanowiący jeden z najważniejszych materiałów konstrukcyjny, pomimo wielu zalet (łatwość stosowania, duża wytrzymałość na ściskanie, mały koszt produkcji, odporność na działanie wysokiej temperatury) posiada też wady, do których zaliczamy przede wszystkim niską wytrzymałość na rozciąganie oraz wrażliwość na niszczące działanie czynników chemicznych. Ciągły wzrost oczekiwań odnośnie podniesienia jakości betonu sprawił, że zaczęto go modyfikować polimerami, które miałby wyeliminować wyżej wymienione wady. Zakres badań obejmował zaprojektowanie i wykonanie mieszanek betonowych modyfikowanych włóknami polipropylenowymi o długości 6, 12, i $19 \mathrm{~mm}$. Do badań użyto: cement portlandzki CEM I 42,5R, piasek, kruszywo żwirowe frakcji 2-8 i 8-16 mm, wodę, plastyfikator Master Pozzolith STD oraz różnej długości włókna polipropylenowe. Wykonano trzy serie betonów zmodyfikowanych włóknami, dla których wyznaczono: wytrzymałość na ściskanie po 7, 28 i 56 dniach dojrzewania oraz nasiąkliwość, gęstość objętościową i mrozoodporność po 100 cyklach zamrażania i rozmrażania. Wykonano również badanie wytrzymałości na rozciąganie przy zginaniu po 28 dniach dojrzewania betonów poszczególnych serii.

Słowa kluczowe: włókna polipropylenowe, beton, wytrzymałość na ściskanie 
